DOI 10.18551/rjoas.2020-07.10

\title{
FACTORS ENCOURAGING THE USE OF PEER-TO-PEER LENDING BY FARMERS
}

\author{
Septiani Hera Laxmi Devi ${ }^{\star}$, Kirbrandoko \\ School of Business, IPB University, Bogor, Indonesia \\ Sumarwan Ujang \\ Faculty of Human Ecology, IPB University, Bogor, Indonesia \\ Yuliati Lilik Noor \\ Department of Family and Consumer Sciences, Faculty of Human Ecology, \\ IPB University, Bogor, Indonesia \\ *E-mail: deardevi@gmail.com
}

\begin{abstract}
Research on the adoption of peer-to-peer (P2P) lending by farmers in agribusiness, such as farming, is still limited. P2P lending is used to address the main challenges of Indonesian smallholder farmers' in accessing financial sources. However, despite its numerous benefits, the adoption rate of this strategy by farmers is still relatively low; therefore, it is essential to encourage its adequate utilization. This research examines the factors that encourage farmers' behavioral intention to adopt the P2P lending strategy in farming funding. The Unified Theory of Acceptance and Use of Technology 2 (UTAUT2) were the variables used. Data were obtained from 371 farmers in West Java, Indonesia, yet to adopt the use of this lending strategy and analyzed using the SEM. The results showed that hedonic motivation, price value, and habit are significantly correlated with behavioral intentions. Therefore, P2P lending providers need to educate farmers on the benefits of adopting this strategy in terms of simplicity, easiness, etc.
\end{abstract}

\section{KEY WORDS}

Consumer behavior, farming funding, peer-to-peer lending, sharing economy, technology adoption, UTAUT2.

According to Kementan (2018), agriculture is the third major sector that contributes tremendously to the Indonesia's national economy after industry and trade. A total of 39.68 million agricultural workers were obtained in February 2018, which was greater than any other sector (BPS 2018). However, there are many limitations associated with handling farmers' welfare levels in agriculture. According to research carried out by Suhari (2013), Indonesian farmers constitute 63.25 percent of the total poor population and live in rural areas. Navajas et al. (2000), Nugroho \& O'hara (2008) and Angioloni et al. (2012) stated that poor income is one of the causes of poverty due to low productivity, technology adoption (Nuryartono et al. 2005) and difficulties in accessing sources of finance (Pasaribu et al. 2007; Rosengard and Prasentyantoko 2011; Sinaga 2011; Arief and Rosmiati 2013). The difficulty associated with accessing finance is due to constraints in land ownership, which are usually needed as collateral, is one of the difficulties associated with accessing finance by agricultural workers (Pattern and Rosengard 1991; Johnston and Murdoch 2008; Anggraeni 2009; Ayyagari et al. 2010).

Financial institutions play an essential role in financing production inputs until the postharvest stage to increase their income. According to the previous studies, the availability of access to financial institutions provides an opportunity for farmers to buy production inputs to increase their value and have an impact on the level of agricultural income (Rahman et al., 2014; Iski et al., 2016; Sekyi et al., 2017). Credit from formal financial institutions, such as banks, are only obtained by farmers with broad land and a strong market network. At the 
same time, those without these factors experience difficulty due to the unavailability of assets as collateral (Rahayu, 2016).

Anggraeni (2009) stated that uncertainty and time lag in the production process does not allow farmers to pay credit.

High risk due to natural disturbance such as flood, drought, pests, and plant diseases, as well as output price fluctuation, is also another reason associated with the limited interest of banking institutions to financing farming. Pratiwi et al. (2019) also included the mismatch of business characteristics in the agribusiness sector and the banking industry as an additional factor.

However, Indiastuti (2005) reported that the bad experience and trauma of handling credits and the inexperience of many major banks in distributing microcredit in line with the regulation of Bank of Indonesia are some of the problems faced by financial institutions. Therefore, the informal source of capital, such as peer-to-peer lending, is one of the options for farmers to get funding (Wineka, 2019; Hermawan \& Adrianyta, 2013; Mulyaqin et al., 2016; Nurmanaf, 2007).

Irrespective of the proven benefits of sharing economy, the acceptance rate of P2P lending among farmers is still relatively low. According to Sembiring (2019), the adoption rate of farmers towards technological advancement in the agribusiness sector is still low. This argument is in line with Boswell's (2004) research on the poor acceptance of technology development, which is an inseparable part of sharing economy (Benkler, 2007; John, 2013; Codagnone and Martens, 2016). The Central Bureau of Statistics Indonesia showed that only $6.60 \%$ of farmers had accessed the internet to achieve financial facility. The difficulty of usage, low benefit awareness, inadequate training, unavailability, and costefficiency are some of the limitations faced by farmers in ICT usage (Taragola et al., 2005; Duerfeldt, 2014).

Bachmann et al. (2011) stated that using ICT makes it easy for borrowers and lenders to connect through the internet using applications and websites.

In November 2019, the Financial Services Authority reported that the number of online loan service providers showed a positive trend with 164 companies. The government's seriousness in developing online loans is contained in OJK Regulation No.77 / POJK.01 / 2016 concerning Information Technology-Based Money Lending and Borrowing Services to regulate electronic transaction activities.

Hadad (2017) stated that online lending services became a disruptive innovation, due to its successful ability to transform an existing system or market, by introducing practicality, ease of access, convenience, and economic costs. An online loan service is a form of financial inclusion aimed at eliminating all forms of price and non-price barriers towards community access to financial services. Therefore, it provides significant benefits in improving people's lives, especially in regions with difficult geographical areas and conditions (Muzdalifa et al. 2018).

The purpose of this research is to provide an adequate understanding of the promoting factors needed for a proper understanding of the P2P lending mechanism among Indonesian farmers.

\section{THEORETICAL REVIEW}

Peer-to-peer lending (P2P Lending). This is the traditional practice of lending money without a mediator (Everett, 2010; Herrero-Lopez, 2009). However, the factor that makes online peer-to-peer lending a new phenomenon is the use of the internet in carrying out transaction activities. According to the Financial Services Authority Regulation (POJK) No. 77 of 2016, this process brings lenders together to make agreements regarding the direct lending of the Rupiah through an electronic system. The motive of the utilization of P2P lending is closely related to the use of internet banking, where transactions are carried out through applications or websites. Previous research stated that the analytical approach was carried out using a combination of the theory of Technology Acceptance Model (TAM) and Theory of Planned Behavior (TPB). These indicators include perceived security risk, financial 
cost, easiness, social influence, trust, previous experience, usefulness, and compatibility (Tan et al. 2010; Nisar and Prabhakar 2017). Based on the costumers, the criteria for choosing a lender include; interest rates, service fees, service provider reputation, sharia, offered facilities, security guarantees, suitability, social influence, availability of information, trust and comfort (Ringim, 2014; Obeid \& Kaabachi, 2016; Sayani \& Miniaoui, 2013; Usman et al. , 2017).

Unified Theory of Acceptance and Use of Technology (UTAUT2). This studies the acceptance and use of technology in the context of mobile applications from costumers' points of view. UTAUT2 includes hedonic motivation, price value, and habits as additional factors to have a direct or indirect impact on behavioral intentions and usage behaviour. The price value is considered important because consumers need to bear the costs of purchasing technology. In addition, the voluntariness of use factor in UTAUT is removed and replaced with new links that facilitate conditions and behavioral intention. In general, UTAUT2 has a more explanatory ability in explaining behavioral intention and the use of technology, because it is inherited from UTAUT, with additional new factors and relationships. Due to its potential to be developed, further research can expand UTAUT2 in different countries, age groups, and technology (Venkatesh et al., 2012).

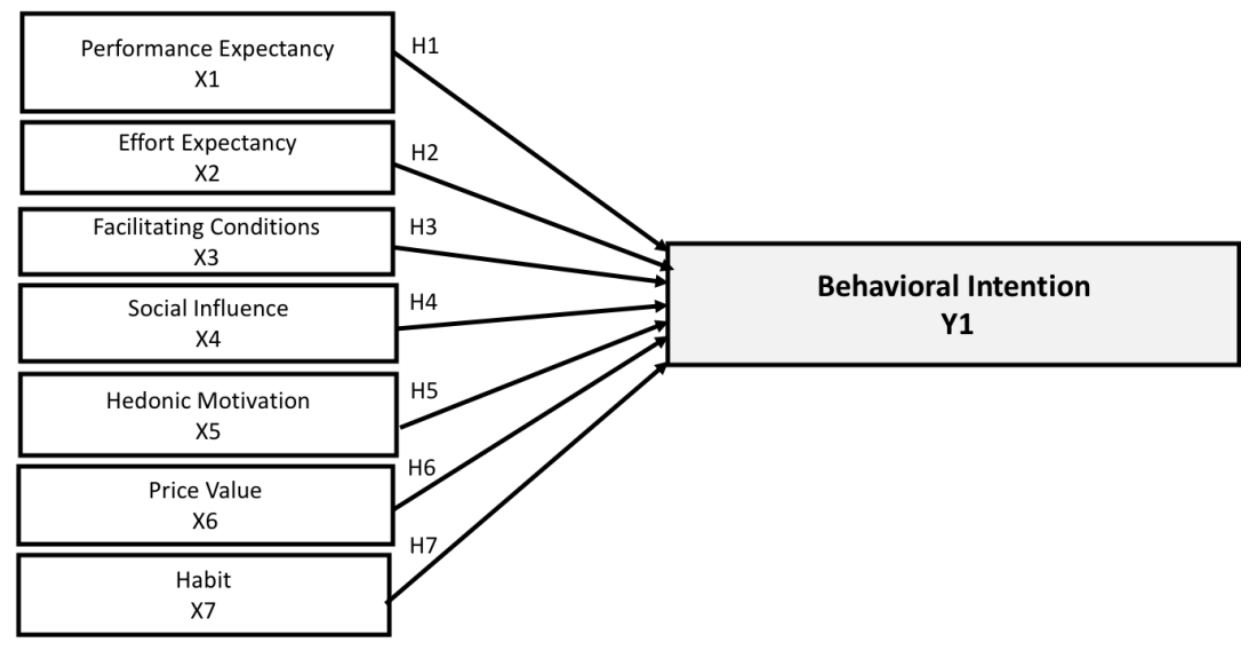

Figure 1 - Conceptual Framework

The research hypotheses are defined as follows:

- H1: Performance expectancy has a positive effect on behavioral intention to adopt P2P lending;

- H2: Effort expectancy has a positive effect on behavioral intention to adopt P2P lending;

- H3: Facilitating condition has a positive effect on behavioral intention to adopt P2P lending;

- H4: Social influence has a positive effect on behavioral intention to adopt P2P lending;

- H5: Hedonic motivation has a positive effect on behavioral intention to adopt P2P lending;

- H6: Price value has a positive effect on behavioral intention to adopt P2P lending;

- H7: Habit has a positive effect on behavioral intention to adopt P2P lending.

\section{METHODS OF RESEARCH}

This is a quantitative research using the confirmatory approach. The purposive sampling method was used to obtain data from 371 farmers in West Java, Indonesia using questionnaires. Initially, the data showed no missing values; however, after further analysis, 15 respondents were found to have provided similar answers to the questions. Therefore, this study utilized valid data from 356 respondents. 
The research consists of dependent and independent variables, such as behavioral intention and the UTAUT2 theory, respectively. Performance and effort expectancy, facilitating conditions, social influence, hedonic motivation, price value, habit, trust, values, and perceived risk are some of the constituents of the UTAUT2 theory.

Furthermore, the Structural Equation Modeling (SEM) technique was used to test the relationship between research variables in the model, while the hypotheses are tested with the farmers as the analysis unit. SEM can investigate and test the hypothesis involving multiple regression analyses among dependent and independent variables (Bentler and Chou, 1987).

Table 1 - Variables of Operationalization

\begin{tabular}{|c|c|c|c|}
\hline No & Variable & Definition & Source \\
\hline 1 & $\begin{array}{l}\text { Performance } \\
\text { Expectancy }\end{array}$ & $\begin{array}{l}\text { The belief that using a system helps to } \\
\text { achieve benefit in work performance }\end{array}$ & $\begin{array}{l}\text { Venkatesh et al. (2012); Botsman and } \\
\text { Rogers, (2010); Kim et al. (2015) }\end{array}$ \\
\hline 2 & Effort Expectancy & $\begin{array}{l}\text { Perception of easiness in using the } \\
\text { technology }\end{array}$ & $\begin{array}{l}\text { Venkatesh et al. (2012); Koufaris \& } \\
\text { Hampton-Sosa (2004); Cao, Zhang, \& } \\
\text { Seydel. (2005) }\end{array}$ \\
\hline 3 & $\begin{array}{l}\text { Facilitating } \\
\text { Conditions }\end{array}$ & $\begin{array}{l}\text { Perception of resource availability which } \\
\text { helps farmers to adapt to technology } \\
\text { easily }\end{array}$ & $\begin{array}{l}\text { Venkatesh et al. (2012); Khalifa and Kathi } \\
\text { (2008); Davis (1989) }\end{array}$ \\
\hline 4 & Social Influence & $\begin{array}{l}\text { The belief of using a new system in } \\
\text { accordance with the surrounding } \\
\text { environment }\end{array}$ & Venkatesh et al. (2012) \\
\hline 5 & $\begin{array}{l}\text { Hedonic } \\
\text { Motivation }\end{array}$ & $\begin{array}{l}\text { Perception towards enjoying the use of } \\
\text { technology }\end{array}$ & Venkatesh et al. (2012); Van der Heijden \\
\hline 6 & Price Value & $\begin{array}{l}\text { Perception towards the amount of } \\
\text { benefits compared to the cost }\end{array}$ & $\begin{array}{l}\text { Venkatesh et al. (2012); Chen and } \\
\text { Salmanian (2017) }\end{array}$ \\
\hline 7 & Habit & Perception towards automatic Behavior & Venkatesh et al. (2012) \\
\hline 8 & $\begin{array}{l}\text { Behavioral } \\
\text { Intention }\end{array}$ & Tendency to adopt P2P lending & $\begin{array}{l}\text { Venkatesh et al. (2012); Davis (1989); } \\
\text { Fishbein \& Ajzen (1975) }\end{array}$ \\
\hline
\end{tabular}

According to Ghozali and Fuad (2008), SEM is an evolution from multiple linear regression developed by combining the econometric and regulation principles of psychology and sociology. It is an integral part of academic, managerial research.

\section{RESULTS AND DISCUSSION}

Majority of the respondent (91.47\%) are male and above the age of 40 as shown in Table 2. This result is in line with an agricultural survey carried out by BPS-Statistics Indonesia (2018), which showed that most Indonesian farmers are above 35 years. According to Martins et al. (2018), age is one of the factors affecting the level of technology adoption.

In terms of education level, $39.08 \%, 30.73 \%, 16.17 \%$, and $12 \%$ are senior high school, elementary, junior, and college graduates, respectively. Survey results also show that most respondents already own a smartphone, while $24 \%$ had none. This result is similar to the findings from BPS - Statistics Indonesia (2018), which showed that only $13.4 \%$ of the total number of farmers used the internet. This means that the adoption level of information technology amongst farmers is still low. Galloway and Mochrie (2005) stated that the delay in adopting the use of ICT in the sub-urban area is due to the supply and demand issue associated with poor technology infrastructure due to the lack of perception towards needs.

The borrowing experience is one of the considerations in the attitude of technology adoption. According to the survey, farmers tend to request conventional loans without using technology (offline) due to children's education, households, and vehicle needs. Approximately $40.31 \%$ use informal financial institutions, such as moneylenders, for their agricultural financing needs through mediators. Furthermore, they use brokers for easier loan application requirements with financial institutions as sources of capital, which are needed by 
farmers for production purposes, daily living, and other social needs. Brokers play various important roles for farmers as capital providers, and in networking, various parties (Megasari, 2017). However, farmers' accessibility to funding sources is minimal, especially for smallholders as the most significant community (Hermawan et al., 2013; Mulyaqin et al., 2016; Nurmanaf, 2007).

Table 2 - Respondent characteristics

\begin{tabular}{|c|c|c|c|}
\hline No. & Respondent Profile & Amount & Percentage \\
\hline \multirow{6}{*}{1} & Age & & \\
\hline & $<30$ & 53 & $14.2 \%$ \\
\hline & $30-39$ & 78 & $21.02 \%$ \\
\hline & $40-49$ & 113 & $30.46 \%$ \\
\hline & $50-59$ & 93 & $25.07 \%$ \\
\hline & $>=60$ & 34 & $9.16 \%$ \\
\hline \multirow{3}{*}{2} & Gender & & \\
\hline & Male & 332 & $89.49 \%$ \\
\hline & Female & 39 & $10.51 \%$ \\
\hline \multirow{7}{*}{3} & Education & & \\
\hline & Elementary school & 114 & $30.73 \%$ \\
\hline & Junior High School & 60 & $16.17 \%$ \\
\hline & Senior High School & 145 & $39.08 \%$ \\
\hline & Diploma & 6 & $1.62 \%$ \\
\hline & Graduate & 45 & $12.13 .7 \%$ \\
\hline & Post Graduate & 1 & $0.27 \%$ \\
\hline \multirow{3}{*}{4} & Mobile phone ownership & & \\
\hline & Owned mobile phone & 320 & $86.25 \%$ \\
\hline & Have no mobile phone & 51 & $13.75 \%$ \\
\hline \multirow{4}{*}{5} & Type of farmer & & \\
\hline & rant land Farmer & 118 & $31.81 \%$ \\
\hline & owned land Farmer & 209 & $56.33 \%$ \\
\hline & Breeder & 44 & $11.86 \%$ \\
\hline
\end{tabular}

Table 3 - Experience in borrowing fund from conventional/offline provider

\begin{tabular}{|c|c|c|c|c|}
\hline No. & & Amount & Percentage & LVS \\
\hline \multirow[t]{3}{*}{1} & Have you ever borrowed funds for non-farming & & & \\
\hline & Yes & 159 & $42.86 \%$ & -0.21 \\
\hline & No & 212 & $51.14 \%$ & -0.78 \\
\hline \multirow[t]{7}{*}{2} & Objectives of borrowing & & & \\
\hline & Children education & 71 & $44.65 \%$ & -0.17 \\
\hline & Buy vehicle & 33 & $20.75 \%$ & -0.37 \\
\hline & Buy electronic goods including mobile phone & 22 & $13.84 \%$ & 0.09 \\
\hline & Buy a house & 3 & $1.89 \%$ & -0.40 \\
\hline & Buy household equipment & 24 & $15.09 \%$ & -0.05 \\
\hline & Others & 6 & $3.77 \%$ & -0.24 \\
\hline \multirow[t]{5}{*}{3} & Lender & & & \\
\hline & Conventional bank & 95 & $59.75 \%$ & -0.06 \\
\hline & Sharia bank & 2 & $1.26 \%$ & -0.67 \\
\hline & Cooperation & 11 & $6.92 \%$ & -0.54 \\
\hline & Others & 51 & $32.08 \%$ & -0.11 \\
\hline \multirow[t]{9}{*}{4} & Consideration of borrowing fund & & & \\
\hline & Low interest & 54 & $6.15 \%$ & -0.37 \\
\hline & Profit-sharing system & 16 & $3.08 \%$ & -0.75 \\
\hline & Low obligation & 26 & $12.31 \%$ & -0.30 \\
\hline & Confidence of payback ability & 38 & $6.15 \%$ & -0.67 \\
\hline & Easy requirements & 98 & $43.08 \%$ & -0.52 \\
\hline & No interest in shariah & 11 & $18.46 \%$ & -0.83 \\
\hline & Bigger benefits & 11 & $4.62 \%$ & -0.62 \\
\hline & Not required to own land & 4 & $6.15 \%$ & -0.44 \\
\hline
\end{tabular}

In this research, the composite reliability test is employed to measure the consistency level, which is higher or equal to 0.70 . Table 4 shows the reliability test of this research shows that all indicators are reliable. 
Table 4 - Reliability test result (Composite Reliability)

\begin{tabular}{lll}
\hline Dimension & CR & Result \\
\hline X1 Performance expectancy & 0.92 & Reliable \\
X2 Effort expectancy & 0.87 & Reliable \\
X3 Facilitating conditions & 0.80 & Reliable \\
X4 Social influence & 0.84 & Reliable \\
X5 Hedonic motivation & 0.92 & Reliable \\
X6 Price value & 0.81 & Reliable \\
X7 Habit & 0.80 & Reliable \\
Y1 Behavioral intention & 0.91 & Reliable \\
\hline
\end{tabular}

*) reliable if $C R>0.70$.

The validity test result on all indicators in this questionnaire shows that the loading factor is above 0.50 , therefore, it has fulfilled the validity requirements; therefore, there is no elimination of variable. Table 5 shows the validity test.

Table 5 - Validity test results (Average Variance Extracted)

\begin{tabular}{lll}
\hline Dimension & AVE & Result \\
\hline X1 Performance expectancy & 0.61 & Valid \\
X2 Effort expectancy & 0.63 & Valid \\
X3 Facilitating conditions & 0.49 & Valid \\
X4 Social influence & 0.63 & Valid \\
X5 Hedonic motivation & 0.63 & Valid \\
X6 Price value & 0.59 & Valid \\
X7 Habit & 0.66 & Valid \\
Y1 Behavioral intention & 0.71 & Valid \\
\hline
\end{tabular}

*) valid if $A V E>0.50$.

The analysis results show that there are three significant correlations with behavioral intention, namely: hedonic motivation, price value, and habit. All relationships are positive.

Table 2 - Path coefficient of the structural model

\begin{tabular}{|c|c|c|c|c|}
\hline Hypothesis & Correlation & Path Coefficient & T-Count & Significance \\
\hline $\mathrm{H} 1$ & $\mathrm{X} 1 \rightarrow \mathrm{Y} 1$ & 0.01 & 0.15 & \\
\hline $\mathrm{H} 2$ & $\mathrm{X}_{2} \rightarrow \mathrm{Y}_{1}$ & -0.08 & -1.00 & \\
\hline $\mathrm{H} 3$ & $\mathrm{X}_{3} \rightarrow \mathrm{Y}_{1}$ & -0.13 & -1.66 & \\
\hline $\mathrm{H} 4$ & $\mathrm{X}_{4} \rightarrow \mathrm{Y}_{1}$ & 0.04 & -0.77 & \\
\hline H5 & $\mathrm{X}_{5} \rightarrow \mathrm{Y}_{1}$ & 0.46 & 4.63 & * \\
\hline $\mathrm{H} 6$ & $\mathrm{X}_{6} \rightarrow \mathrm{Y}_{1}$ & 0.24 & 2.62 & * \\
\hline $\mathrm{H} 7$ & $\mathrm{X} 7 \rightarrow \mathrm{Y} 1$ & 0.41 & 3.72 & * \\
\hline
\end{tabular}

Note: Symbol $\left({ }^{*}\right)$ shows Path Coefficient significant at the error rate 5\%, in which absolute $t$-count $>1.96$.

In accordance with hypothesis 5, hedonic motivation (X5) positively influences behavioral intention to adopt P2P lending. The analysis also shows that P2P lending intention has the strongest relationship adoptive behavior compared to price values and habits at a path coefficient of 0.23 . These results are similar with the several previous studies, which showed the positive effect of hedonic motivation on behavioral intention to adopt the technology (Leong et al., 2017; Yapp et al., 2018; Martins et al., 2018; Salarzadeh et al., 2017; Lin, Wang, \& Wu 2017; Tak \& Panwar 2017). The hedonic motivation in this study was measured from farmers' perceptions of using peer-to-peer lending applications and services, which provided pleasant experiences, easy access, and respondent enthusiasm. Price value (X6) also showed a positive relationship with behavioral intention using a path coefficient of 0.17 and t-count above 1.64; therefore, Hypothesis 7 was accepted. Mohd Isa \& Wong (2015), Leong et al. (2017), Hew et al. (2015), Lin et al. (2017), and Tarhini et al. (2017), assumed that the use of technology reduces costs. Meanwhile, farmers assumed that peer-to-peer lending benefits are greater than the costs incurred; therefore, it provides easier access and obligations. 
Tak \& Panwar (2017) stated that many people are addicted to the use of online media. This is in line with the analysis results, which stated that habits are variables with a significant positive effect on behavioral intentions to adopt peer-to-peer lending. Habit (X7) shows a positive relationship with behavioral intention using a path coefficient of 0.05 and a t-count above 1.96; therefore, Hypothesis 8 was accepted. This is in accordance with the UTAUT2 theory developed by Venkatesh et al. (2012). The habit of conducting other online activities such as social media and shopping is an indicator that active users of electronic devices have greater ability to adopt to new technologies (Venkatesh \& Zhang, 2010).

According to the analysis of the results above, hedonic motivation, price values, and inadequate information and habits significantly influence the behavioral intention of farmers in adopting peer-to-peer lending. Therefore, intensive socialization is needed with a direct approach through field agents to demonstrate the benefits of technology utilization to accelerate the process.

Furthermore, socialization, practice, and training on the use of application and website technologies is needed to obtain the maximum benefits of the P2P lending economy in agricultural farming (Nurmawiya \& Kurniawan 2019).

\section{CONCLUSION}

In conclusion, the various factors that influences behavioral intention in adopting a peer-to-peer lending sharing economy in agricultural financing were analyzed in this study. The results indicate that hedonic motivation, price value, and habits influence farmers' behavioral intention in adopting a sharing economy strategy. Due to farmers' limited access to internet services, a more socialization approach is needed regarding the benefits of using technology to accelerate their ability to access agricultural financing.

This research is similar with the previous studies, where hedonic variables, price values, and habits had a significant and positive effect on farmers' behavioral intention in adopting peer-to-peer lending in agricultural financing. Furthermore, performance, effort expectancy, and social influence, also showed a positive impact on behavioral intention, which was insignificant at an error level of $5 \%$. Therefore, further research needs to be conducted on a more significant number of respondents in the broader area using the questionnaire to obtain better generalizations on the adoption of peer-to-peer lending in agricultural financing among Indonesian farmers.

\section{REFERENCES}

1. Anggraeni L. 2009 The Function of Social Networks for Informal Credits in Remote Rural Areas in Indonesia [Disertasi]. Tokyo (JP): The University of Tokyo.

2. Angioloni S, Z Kudabaev, GCW Ames, and M Wetzstein. 2012. Micro-credit Impact in Kyrgystan : A Study Case. [Paper]. The University of Georgia.

3. Arief B dan M Rosmiati. 2013. Dampak Akses Kredit terhadap Kesejahteraan Rumah Tangga Petani Padi. Jurnal Institut Koperasi Indonesia. pp: 129- 138.

4. Ayyagari M, AD-Kunt, and V Maksimovic. 2010. Formal versus Informal Finance: Evidence from China. The Review of Financial Studies. Vol 23 No. 8, pp: 3048-3097.

5. Bachmann, Alexander; Alexander Becker; Daniel Buerckner; Michel Hilker; Frank Kock, Mark Lehmann; Philip Tiburtius; Burkhardt Funk. (2011). "Online Peer-to-Peer Lending A Literature Review". Journal of Internet Banking and Commerce, 16(2), 1-18.

6. Benkler, Yochai. (2007). "The Wealth of Networks: How Social Production Transforms Markets and Freedom". New Haven: Yale University Press

7. Bentler, P.M., Chou, C.P. (1987). Practical issues in structural modelling. Sociological Methods \& Research, 16(1), 78-117.

8. Boswell, Katherine (2004). "The Impact of Perceived Invasiveness and Perceived Objective on Technology Acceptance: An Extension to The Technology Acceptance Model". [disertasi]. Mississippi (US): University of Mississippi 
9. Botsman, Rachel; Roo Rogers. (2011). What's Mine is Yours: How Collaborative Consumption is Changing the Way We Live". HarperCollins Publishers: New York, NY, USA.

10. BPS. 2013. Laporan Hasil Pertanian 2013. http://st2013.bps.go.id/

11. Cao, M., Zhang, Q., \& Seydel, J. (2005), B2C e-commerce web site quality: an empirical examination. Industrial Management \& Data Systems, Vol. 105 No. 5, pp. 645-61

12. Chen Y, Salmanian W. (2017). User acceptance in the sharing economy. An explanatory study of transportation network companies in China based on UTAUT2. Jonkoping University. Finland.

13. Codagnone, Cristiano; Bertin Martens. (2016). "Scoping the Sharing Economy: Origins, Definitions, Impact and Regulatory Issues. JRC Technical Reports", Institute for Prospective Technological Studies Digital Economy Working Paper 2016/01.

14. Davis, Fred D. (1989). "Perceived Usefulness, Perceived Ease of Use, and User Acceptance of Information Technology". MIS Quarterly. 13(3):319-340.

15. Duerfeldt, Kevin R. (2014). "Values-based Supply Chains: Local and Regional Food Systems in the Upper Midwest United States". lowa (US): lowa State University

16. Everett, Craig R. (2010). "Group Membership, Relationship Banking and Loan Default Risk: The Case of Online Social Lending Group". West Lafayette, IN. Retrieved from Available at SSRN: http://ssrn.com/abstract $=1114428$

17. Fishbein, M., Ajzen, I. (1975). Belief, attitude, intention and Behavior: An introduction to theory and research. Addison-Wesley Publishing Company.

18. Ghozali, Imam; Fuad. (2008). Structural Equation Modelling. Badan Penerbit Universitas Diponegoro. Semarang.

19. Hadad, M. D. 2017. Pengembangan "Fintech" Tetap Mengarah pada P2L. Retrieved on 20 June 2020 at https://money.kompas.com/

20. Hermawan, Hari; Harmi Adrianyta. (2013). "Peran Tambahan Modal Terhadap Pendapatan Usahatani Padi." (10): 132-39.

21. Herrero-Lopez, Sergio. (2009). "Social Interactions in P2P Lending". Proceedings of the 3rd Workshop on Social Network Mining and Analysis (pp. 1-8). Paris: ACM. Retrieved from http://portal.acm.org/citation.cfm?id=1731011.1731014

22. Hew, Jun Jie; Voon Hsien Lee; Keng Boon Ooi; June Wei. (2015). "What Catalyses Mobile Apps Usage Intention: An Empirical Analysis." Industrial Management and Data Systems 115(7): 1269-91.

23. Indiastuti R. 2005. Arti Tahun Keuangan Mikro bagi Indonesia. Retrieved from: http: www.pikiran-rakyat.com/cetak/2005/0305/08/0608.htm [12/03/18]

24. Indonesian Financial Service Authority (OJK). (2016). Regulation on information technology-based lending or Fintech. Retrieved on 11 December 2019 from https://www.ojk.go.id/id/Regulasi/Default.aspx

25. Iski, N., Kusnadi, N., \& Harianto, H. (2016). Pengaruh Kredit terhadap Pendapatan Petani Kopi Arabika di Kabupaten Aceh Tengah Provinsi Aceh. Jurnal Manajemen \& Agribisnis, 13(2), $132-144$.

26. John, Nicholas A. (2013). "Sharing, Collaborative Consumption and Web 2.0." Media@Lse Retrieved (26): 17 July 2014.http://www.Ise.ac.uk/

27. Johnston D and J Murdoch. 2008. The Unbanked: Evidence from Indonesia. The World Bank Economic Review. Vol. 22 No. 3, pp: 517-537.

28. Khalifa, M., Kathy, S.N. (2008). Drivers for transactional b2c m-commerce adoption: extended theory of planned behavior. Journal of Computer Information Systems.

29. Kementan.(2018). Ini Kontribusi Positif Sektor Pertanian. https://biz.kompas.com/

30. Kim, Changsu; In-Seok Lee; Tao Wang; Mirsobit Mirusmonov. (2015 "Evaluating Effects of Mobile CRM on Employees' Performance". Industrial Management \& Data Systems. Vol. 115 No. 4, 2015 pp. 740-764

31. Koufaris M, Hampton-Sosa, W. (2004) The development of initial trust in an online company by new customers. Information Management 41(3):377-397.

32. Leong, Gan Wee; Teoh Ai Ping; Rajendran Muthuveloo. (2017). "Antecedents of Behavioral Intention to Adopt Internet of Things in the Context of Smart City in Malaysia." 
Global Business and Management Research: An International Journal 9(4s): 442-56. https://0-search-proquest-com.oasis.unisa.ac.za/

33. Lin, Huey-Yeh; Mei-Hsiang Wang; Min-Jhen Wu. (2017). "A Study of Airbnb Use Behavior in the Sharing Economy." International Journal of Organizational Innovation 10(1): 38-47. http://search.ebscohost.com/

34. Martins, Mateus; Josivania Silva Farias; Pedro Henrique Melo Albuquerque; Danilo Santana Pereira. (2018). "Adoption of Technology for Reading Purposes: A Study Articles of e-Books Acceptance." Brazilian Business Review 15(6): 568-88.

35. Megasari L. (2017). Ketergantungan petani terhadap tengkulak sebagai patron dalam kegiatan proses produksi pertanian (studi di Desa Baye Kecamatan Kayen Kidul Kabupaten Kediri) http://repository.unair.ac.id/

36. Mohd Isa, Salmi; Khang Yeu Wong. (2015). "Age Differences in Behavioral Intention to Use Internet Marketing: A Comparative Study between Malaysian and Taiwanese." International Journal of Business and Society 16(3): 386-96.

37. Mulyaqin, Tian; Yati Astuti; Dewi Haryani. (2016). "Faktor yang Mempengaruhi Petani Padi dalam Pemanfaatan Sumber Funding: Studi Kasus di Kabupaten Serang Provinsi Banten." 2(1): 2016.

38. Muzdalifa, I., Rahma, I. A., \& Novalia, B. G. (2018). FinTech's Role in Enhancing Inclusive Finance in UMKM in Indonesia (Sharia Financial Approach). Masharif AlSyariah: Jurnal Ekonomi dan Perbankan Syariah, 3(1).

39. Navajas S, M. Schreiner, R.L. Meyer, C.G. Vega, and J.R. Meza. 2000. Microcredit and The Poorest of The Poor: Theory and Evidence from Bolivia. Elsevier Science. Vol. 28 No. 2, pp: 333-346.

40. Nugroho AE and PA O'hara. 2008. Microfinance Sustainability and Poverty Outreach: A Case Study of Microfinance and Social Capital in Rural Java, Indonesia. [Working Paper]. Perth: Global Political Economic Research Unit.

41. Nurmanaf, Achmad Rozany. (2007). "Lembaga Informal Pembiayaan Mikro Lebih Dekat Dengan Petani." Analisis Kebijakan Pertanian 5(2): 99-109. http://pse.litbang.pertanian.go.id/ind/pdffiles/ISU5-2a.pdf.

42. Nurmawiya; Robert Kurniawan. (2019). "Analisis Kesiapan Petani Dalam Menghadapi Era Revolusi Industri 4.0." Seminar Nasional Pembangunan Pertanian III O(July).

43. Nuryartono N, Zeller M, and Schwarze S. 2005. Credit Rationing of Farm Households and Agricultural Production: Empirical Evidence in The Rural Areas of Central Sulawesi, Indonesia [Makalah].

44. Obeid, Hassan; Souheila Kaabachi. (2016). "Empirical Investigation into Customer Adoption of Islamic Banking Services in Tunisia." Journal of Applied Business Research 32(4): 1243-56.

45. Pasaribu S, B Sayaka, WK Sejati, A Setiyanto, J Hestina, dan J Situmorang. 2007. Analisis Kebijakan Pembiayaan Sektor Pertanian. [Makalah Seminar]. Pusat Analisis Sosial Ekonomi dam Kebijakan Pertanian.

46. Pattern RH and JK Rosengard. 1991. Progress with Profits: The Development of Rural Banking in Indonesia [Working Paper]. San Francisco (AS): International Center for Economic Growth.

47. Pratiwi DE, Ambayoen MA, \& Hardana AE. 2019. Studi pembiayaan mikro petani dalam pengambilan keputusan untuk kredit formal dan kredit nonformal. HABITAT, 30(1): 3543. https://doi.org/10.21776/ub.habitat.2019.030.1.5

48. Rahman, S., Hussain, A., \& Taqi, M. (2014). Impact of agricultural credit on agricultural productivity in Pakistan: An empirical analysis. International Journal of Advanced Research in Management and Social Sciences, 3(4), 125-139.

49. Rahayu, L. (2016). Aksesibilitas petani bawang merah terhadap lembaga keuangan mikro sebagai sumber pembiayaan. AGRARIS: Journal of Agribusiness and Rural Development Research, 1(1), 52-60.

50. Ringim, Jinjiri Kabiru. (2014). "Perception of Nigerian Muslim Account Holders in Conventional Banks toward Islamic Banking Products." International Journal of Islamic and Middle Eastern Finance and Management 7(3): 288-305. 
51. Rosengard, JK and A Prasentyantoko. 2011. If the Banks are Doing So Well, Why Can't I Get a Loan? Regulatory Constraints to Financial Inclusion in Indonesia. Asian Economic Policy Review. Vol. 6, pp: 273-296.

52. Salarzadeh, Jetanabadi Hashem; Sedigheh Moghavvemi; Che Wan Jasimah Bt Wan Mohamed Radzi; Parastoo Babashamsi; Mohammad Arashi. (2017). "Testing Students' e-Learning via Facebook through Bayesian Structural Equation Modeling." PLoS ONE 12(9): 1-20. http://dx.doi.org/10.1371/journal.pone.0182311.

53. Sayani, Hameedah; Hela Miniaoui. (2013). "Determinants of Bank Selection in the United Arab Emirates." International Journal of Bank Marketing 31(3): 206-28.

54. Sekyi, S., Abu, B. M., \& Nkegbe, P. K. (2017). Farm credit access, credit constraint and productivity in Ghana: Empirical evidence from Northern Savannah ecological zone. Agricultural Finance Review, 77(4), 446-462

55. Sembiring, J.M. (2019). The business model of online-based aggregator. Bogor Agricultural University.

56. Sinaga R. 2011. Analisis Kredit dan Pengaruhnya terhadap Usahatani Tomat dan Kentang [Tesis]. Bogor (ID): Institut Pertanian Bogor.

57. Suhari I. (2013). Sensus Pertanian 2013, Melihat Lebih Dekat Kondisi Petani Indonesia. Kompasiana [Internet]. [diunduh 2013 Des 22]; Tersedia pada: http://m.kompasiana.com/

58. Tak, Preeti; Savita Panwar. (2017). "Using UTAUT 2 Model to Predict Mobile App Based Shopping: Evidences from India." Journal of Indian Business Research 9(3): 248-64.

59. Tan Chin-Seang; Hooi-Yin Ooi; Yen-Nee Goh. (2017). "A Moral Extension of the Theory of Planned Behavior to Predict Consumers' Purchase Intention for Energy-Efficient Household Appliances in Malaysia". Energy Policy 107:459-471. doi: 10.1016/j.enpol.2017.05.027.

60. Taragola Nicole D.; Dirk Van Lierde, E. Gelb. (2005). "Information and Communication Technology (ICT) Adaption in Comparison to the EFITA Baseline". In J. Boaventura Cunha \& R Morais (Eds.). Proceedings of the EFITA/WCCA 2005 Joint Conference. Vila Real. Universidade De Tras-os-Montes e Alto Douro. Portugal.

61. Tarhini, Ali; Ra'Ed Masa'deh; Kamla Ali Al-Busaidi. (2017). "Factors Influencing Students' Adoption of e-Learning: A Structural Equation Modeling Approach." Journal of International Education in Business 10(2): 164-82.

62. Usman, Hardius; Prijono Tjiptoherijanto; Tengku Ezni Balqiah; I. Gusti Ngurah Agung. (2017). "The Role of Religious Norms, Trust, Importance of Attributes and Information Sources in the Relationship between Religiosity and Selection of the Islamic Bank." Journal of Islamic Marketing 8(2): 158-86.

63. Van der Heijden, H., Verhagen, T., \& Creemers, M.(2003). Understanding online purchase intentions: contributions from technology and trust perspectives. European Journal of Information Systems. Vol. 12, pp. 41-8.

64. Venkatesh, Viswanath; James Y.L. Thong; Xin Xu. (2012). "Consumer Acceptance and Use of Information Technology: Extending the Unified Theory of Acceptance and Use of Technology". MIS Quarterly, 36 (1), 157-178.

65. Venkatesh, Viswanath; Xiaojun Zhang. (2010). "Unified Theory of Acceptance and Use of Technology: U.S. Vs. China". Journal of Global Information Technology Management Vol. 13(1).

66. Wineka P. 2019. E-Commerce and P2P lending Tanihub received series a funding USD 10 million. Retrieved on 10 June 2019 from: https://teknologi.bisnis.com/

67. Yapp, Emily H.T.; Chaaminy Balakrishna; Jasmine A.L. Yeap; Yuvaraj Ganesan. (2018). "Male and Female Technology Users' Acceptance of On-Demand Services". Global Business and Management Research: An International Journal. Vol. 10, No. 1 (2018, Special Issue). 